\title{
IfIISGUCDERGI.ORG
}

"İȘ, GÜç̣" ENDÜSTRi iLIȘKiLERi VE INSAN KAYNAKLARI DERGiSi

"IS, GUC" INDUSTRIAL RELATIONS AND HUMAN RESOURCES JOURNAL

\section{Precarious Work Versus Decent Work: The Precariousness From The Perspectives Of Service Sector Employees In Turkey The Case Of Bursa}

\author{
Assoc. Prof. Dr. Özlem IŞIĞIÇOK \\ Departmant of Labour Economics and Industrial Relations, \\ Uludağ University, Bursa, Turkey \\ ozlemi@uludag.edu.tr \\ Res. Assistant Burak Faik EMİRGIL \\ Departmant of Labour Economics and Industrial Relations, \\ Uludağ University, Bursa, Turkey \\ emirgil@uludag.edu.tr
}

Ekim/October 2009, Cilt/Vol: 11, Say1/Num: 5, Page: 79-94 ISSN: 1303-2860, DOI: 10.4026/1303-2860.2009.0127.x

Makalenin on-line kopyasına erişmek için:

http://www.isgucdergi.org/?p=makale\&id=399\&cilt=11\&sayi=5\&yil=2009

To reach the on-line copy of article:

http://www.isguc.org/?p=article\&id=399\&vol=11\&num=5\&year=2009

Makale İçin İletişim/Correspondence to:

Yazarların e-posta adresleri verilmiştir. Writers e-mail was given for contact. 
(C) 2000- 2009

"İşGüç̧" Endüstri İlişkileri ve İnsan Kaynakları Dergisi

"İşGǚç" Industrial Relations and Human Resources Journal

Ekim/October 2009, Cilt/Vol: 11, Say1/Num: 5

ISSN: 1303-2860, DOI: 10.4026/1303-2860.2009.0127.x

Editör/Editor-in-Chief

Aşkın Keser (Kocaeli University)

Editör Yardımcıları/Co-Editors

K.Ahmet Sevimli (Uludă̆ University)

Gözde Yulmaz (Kocaeli University)

Uygulama/Design

Yusuf Budak (Kocaeli Universtiy)

\author{
Yayin Kurulu / Publishing Committee \\ Dr.Zerrin Firat (Uludă̆ University) \\ Doç.Dr.Aşkın Keser (Kocaeli University) \\ Prof.Dr.Ahmet Selamoğlu (Kocaeli University) \\ Yrd.Doç.Dr.Ahmet Sevimli (Uludağ University) \\ Yrd.Doç.Dr.Abdulkadir Şenkal (Kocaeli University) \\ Yrd.Doç.Dr.Gözde Yilmaz (Kocaeli University) \\ Dr.Memet Zencirkıran (Uludağ University)
}

Uluslararası Danışma Kurulu / International Advisory Board

Prof.Dr.Ronald Burke (York University-Kanada)

Assoc.Prof.Dr.Glenn Dawes (James Cook University-Avustralya)

Prof.Dr.Jan Dul (Erasmus University-Hollanda)

Prof.Dr.Alev Efendioğlu (University of San Francisco-ABD)

Prof.Dr.Adrian Furnham (University College London-İngiltere)

Prof.Dr.Alan Geare (University of Otago- Yeni Zellanda)

Prof.Dr. Ricky Griffin (TAMU-Texas AEM University-ABD)

Assoc. Prof. Dr. Diana Lipinskiene (Kaunos University-Litvanya)

Prof.Dr.George Manning (Northern Kentucky University-ABD)

Prof. Dr. William (L.) Murray (University of San Francisco-ABD)

Prof.Dr.Mustafa Özbilgin (University of East Anglia-UK)

Assoc. Prof. Owen Stanley (James Cook University-Avustralya)

Prof.Dr.Işık Urla Zeytinoğlu (McMaster University-Kanada)

Danışma Kurulu / National Advisory Board

Prof.Dr.Yusuf Alper (Uludağ University)

Prof.Dr.Veysel Bozkurt (Uludağ University)

Prof.Dr.Toker Dereli (Işık University)

Prof.Dr.Nihat Erdoğmuş (Kocaeli University)

Prof.Dr.Ahmet Makal (Ankara University)

Prof.Dr.Ahmet Selamoğlu (Kocaeli University)

Prof.Dr.Nadir Suğur (Anadolu University)

Prof.Dr.Nursel Telman (Maltepe University)

Prof.Dr.Cavide Uyargil (İstanbul University)

Prof.Dr.Engin Yildırım (Sakarya University)

Doç.Dr.Arzu Wasti (Sabancı University)

Dergide yayınlanan yazılardaki görüşler ve bu konudaki sorumluluk yazarlarma aittir.

Yayınlanan eserlerde yer alan tüm içerik kaynak gösterilmeden kullanılamaz.

All the opinions written in articles are under responsibilities of the outhors.

None of the contents published can't be used without being cited. 


\title{
Precarious Work Versus Decent Work: The Precariousness From The Perspectives Of Service Sector Employees In Turkey The Case Of Bursa
}

\author{
Assoc. Prof. Dr. Özlem IŞIĞIÇOK \\ Departmant of Labour Economics and \\ Industrial Relations, \\ Uludağ University, Bursa, Turkey
}

\author{
Res. Assistant Burak Faik EMİGít \\ Departmant of Labour Economics and \\ Industrial Relations, \\ Uludağ University, Bursa, Turkey
}

\begin{abstract}
:
The most direct consequence of the expansion of non-standard employment contracts in labour market becomes "precarious work", which is characterized by job insecurity, job instability and involuntariness for nonpermanent jobs. Non-standard employment forms which are implemented increasingly in service sector as a result of attempts to make Turkish labour market more flexible, make it compulsory to problematize the precarious experience of employees. This qualitative study aims to explore how those, who are employed under fixed-term contracts, experience job insecurity and job instability and whether the experience of precariousness differentiates according to the age, gender and educational level. According to the findings of the semi-structured in-depth interviews made with 21 employees working in cleaning and security sectors operating in Bursa, phenomenon of job insecurity is experienced as the increase of unemployment risk, the danger of not finding a job again in the labour market after falling out of the job, and loss of foresight pertaining to the future in the working life. As for the job instability, it arises as both the gradual loss of employees' abilities to build their careers and postponement of short term and long term decisions in their everyday lives. On the other hand, all participants' accepting their jobs compulsorily completes the precariousness characteristics of their jobs. Furthermore, it was found that those who were influenced by job insecurity and job instability utmost are women and young people who have high level of education. These findings point out that precariousness peculiar to service sector jobs in Turkey causes multi-dimensional problems for temporary employees.
\end{abstract}

Keywords: precarious employment, fixed-term employment contracts, job insecurity, job instability, service sector. 


\section{Introduction}

Global competitive pressures drive enterprises into downsizing and outsourcing, which reconstructs labour markets by causing them to be flexible. One of the most important results of this change experienced in labour markets is the gradual expansion of "nonstandard" contracts. This is realised through a transition from "permanent jobs" that are based on full-time and open-ended employment contracts regarded as standard employment forms to "temporary jobs" that are based on nonstandard "part-time" and "fixed-term employment contracts" (Kalleberg, 2000). It is possible to observe this transition clearly in the European Union (EU) and its 27 members. Focusing on changes in employment forms within EU countries during $2000-2007,4.9 \%$ of the relative employment increase recorded during this period was due to full-time employment, while $17.7 \%$ was due to part-time employment. Moreover, while $5.4 \%$ of this increase was due to permanent employment, $24.6 \%$ was due to temporary employment (EU Commission, 2008: 29).

Nevertheless, differentiation arising in the content and nature of social protection due to expansion of non-standard employment contracts creates many negative results for employees; moreover, it is certain that an increase in job insecurity and job instability leads to these problems (Elliott and Atkinson, 1998; Heery and Salmon, 2000). Those who are employed in temporary work arrangements are particularly affected by this situation, and as a result, the workers included in this group are more influenced by job insecurity (Saloniemi and Zeytinoglu, 2007). Furthermore, this situation inordinately affects young people, women and low-skilled individuals, the latter of whom are more frequently employed with non-standard employment contracts (Tucker, 2002; Zeytinoglu and Muteshi, 2000). Employment that becomes precarious constitutes the basic dynamics of the phenomenon under study. At the same time, this situation in the labour market has led some scholars to consider an increase in risks and uncertainties in the labour market (Davoine et al., 2008a; EU Commission, 2008). Within this framework, the concept of decent work has been raised on the agenda of the International Labour Organization (ILO) as a way of addressing this situation through increased social protection and employment security to insure workers against poor-quality, precarious employment that has emerged as a result of the newly flexible labour markets (Boyer, 2006; Vosko, 2002; Fields, 2003; Auer, 2006; Isigicok, 2009). In this context, it is certain that the phenomenon of decent work includes that the basic rights of the workers are protected in their working lives; a sufficient income and social security are provided; and the quality and quantity of employment associated with an increase in the quality of jobs together are the most efficient instruments and precautions to cope with the problems arising from labour market flexibility.

The historical attempts to develop a flexible labour market in Turkey date back to the economic liberalisation policies, including financial and commercial liberalisation and opening to foreign capital and privatisation, all of which have been applied in tandem with the European Union membership process since 2000s. In addition, the new labour law no. 4857 introduced in 2003 has had a crucial role in this matter. As a matter of fact, the fact that this new labour law provided the legal ground for non-standard employment forms such as "part-time working," "temporary employment relationship" and "work on call" has enabled the Turkish labour market to turn into a more flexible structure. This new arrangement in the labour market has brought about a significant increase in certain kinds of employment, especially the employment of low-skilled women and young people in the service sector (Ercan, 2007; Toksoz, 2007; 2009). However, this situation has increased the number of individuals who work under non-standard employment contracts and who encounter more serious job insecurities and 
instability in Turkey. Considering the general characteristics of the Turkish labour market, sectoral distribution and quality of employment, it is possible to argue that precariousness is intensive in the service sector, and thus, negative results caused by precariousness have the most intense influence on those who are employed in the service sector.

This study aims to present subjective evidences pertaining to job insecurity and job instability by discussing the precariousness evaluations of fixed-term service sector employees in Turkey. To this end, after precarious employment is outlined in the first section of the study, in second section, the "precariousness influence" is discussed in terms of service sector workers in the Turkish labour market. In the following section, methodological approach relating to qualitative research of the study is explained and the findings are presented. Finally, the last section discusses the dynamics and dimensions of precarious employment in Turkey.

\section{Precarious Employment versus Decent Employment}

Although it is difficult to develop a clear definition of precarious employment, the concept is seen as an aggregate of job insecurity, job instability and involuntariness for temporary working, all of which are encountered within non-standard employment (Temiz, 2004). In fact, various definitions of the concept of precarious employment have been forwarded. For instance, the ILO defined precarious employment as employment relations in which employment security as a basic element of employment contracts is deficient. However, as a concept, precarious employment includes not only those working without job security but also workers who are exposed to poor working conditions due to high levels of employment uncertainty and low wages. In this context, the concept of precarious employment is used as a general expression for "inequality," "uncertainty," "instability" and "insecurity" related to participation in the labour market
(Temiz, 2004).

In addition, precarious employment has a multi-dimensional feature as a concept. In this sense, it is beneficial to highlight the three main elements of "job insecurity," "job instability" and "involuntariness for temporary employment." We might say that job insecurity refers to a decrease in legal rights and low-level social protection as generally compared to employees working under standard contract forms. In addition to the fact that it is based on "objective" criteria such as working conditions (i.e., the type of contract, wages, working hours, social rights and so on) and legal regulations that are the indicators of increasingly insecure employment, it is necessary to take into account "subjective" criteria, including the perceptions of workers (Fournier et al., 2003; Bujold and Fournier, 2008; Näswall and De Witte, 2003). From this point of view, the subjective conceptualisation of job insecurity basically constitutes a source of anxieties and threats that individuals perceive about today's and the future's employment situations (De Witte and Näswall, 2003). Job instability, as the second feature of precariousness, arises as a result of an increase in non-permanent jobs due to the increasingly transitional nature of the labour market (Schimd, 2002; Gazier 2002). While on the one hand, the fact that employees work in unstable employment implies that their careers are fragmented and unclear, on the other hand, employees increasingly lose control over their jobs and lives (Sennett, 1998). Involuntary non-standard working (Gallagher and Sverke, 2005: 183; Sverke and Hellgren, 2002), which is the last aspect of precariousness, means that employees work in inferior jobs that have poor working conditions and are vulnerable given the requirements of these jobs. For instance, part-time employment may be preferred voluntarily, but fixed-term employment is accepted involuntarily within the member countries of the EU (EC, 2008: 34). This situation draws attention to the relationship between fixedterm employment and precariousness. 
Measures to empirically understand the influences of precarious employment on employees and, in turn, minimise the negative results of precariousness were introduced for the first time when the concept of decent work was conceptualised by the ILO in 1999 (Anker et al., 2003; Bescond et al., 2003). As a target of these measures, decent work has four basic elements, namely, the improvement of working rights, employment, social protection and social dialogue (Ghai, 2003). In fact, the measurement of the dimensions and elements of decent work both at a macro (or national) level and at the micro (or workplace) level continues to be studied. With these aims, the "Tripartite Meeting of Experts on the Measurement of Decent Work" was arranged by ILO in 2008, and a draft called the "Decent Work Indicators Index" was prepared. These indicators include employment opportunities, sufficient income, productive employment, decent working hours, integration of working life with family and individual life, jobs that should be abolished, security and stability of employment, opportunity and treatment equality in employment, job security, social security, social dialogue, and the representation of employees and employers. While all of these indicators demonstrate precarious employment, the security and stability of employment and the integration of working life with family and individual life make it possible to measure precariousness directly (ILO, 2008). However, it is necessary to emphasise that all of these criteria are objective criteria.

Alternatively, the job quality approach, which was put on the agenda of European Commission in 2001 within the scope of European Employment Strategy, is integral to the decent work approach of the ILO (Davoine et al. 2008b). So-called "Laekan indicators" developed to measure the quality of jobs are comprised of four dimensions. Dimensions (and indicators) include socio-economic security (intrinsic job quality, flexibility and security, inclusion and access to the labour market, diversity and non-discrimination), training (lifelong learning and career development, overall economic performance and productivity), working conditions (health and safety at work, social dialogue, and worker involvement) and the reconciliation of working and non-working life and gender balance (work organisation and the work- life balance, gender equality) (EC, 2008). Therefore, the EU's approach towards measuring job quality includes the perceptions of employees, as this approach takes subjective variables into consideration as well as objective criteria, thereby taking measurements at the workplace level.

\section{The Impact of Precariousness on Employment Relations in Turkey}

Since the basic characteristics of the labour market reflect the general features of employment relations in Turkey (Yildirim and Calis, 2008: 214), an examination of the structure of the labour market allows us to make inferences regarding precarious work situations. In this context, it is useful to consider the rate of participation in the workforce, the employment rate and the unemployment rate in the Turkish labour market. In 2008, the rate of participation in the workforce in Turkey was $46.9 \%$, which is very low compared to developed countries. In the same way, the employment rate was very low as well at the rate of $41.7 \%$. Note that $23.7 \%$ of those employed in 2008 worked in agriculture sector, with $21 \%$ of them in the industrial sector, $5.9 \%$ were in the construction sector, and $49.5 \%$ worked in the service sector. (TÜİK, 2009). The most important reason for these low rates is that the participation of women in the workforce in urban areas is a third as much as that of men (World Bank, 2006: 9). In that same year, while general unemployment rate was $11 \%$, this rate was higher in urban areas. The unemployment rate has shown an increase, particularly among young people in the last decade, with this rate rising to $20.5 \%$ in 2008 . In addition to this negative result, Ercan (2007: 30) discusses that "paradoxically, in an environment where average education levels are low and employers prefer skilled workmen, unemployment rate among the educated 
young people (high school graduates and above) is relatively higher." The prolongation of unemployment is among the structural problems faced in the labour market, particularly by women (Tansel and Tasci, 2004; Tunali, 2003: 56) and young people (Ercan, 2007).

In addition to the present situation of the formal workforce, the high informal employment rate of approximately $50 \%$ of the employed population in Turkey directly influences employment relations as one of the basic characteristics of the labour market. The most important factors that play a part in the expansion of informal employment include the existence of an unskilled workforce migrating from rural areas to the urban; a lack of sufficient proper employment in cities; and the fact that small and mid-size enterprises encourage informal workforce employment and constitute $98 \%$ of economical enterprises in Turkey. As can be understood from several main indicators presented above, it is possible to determine that the structure of the labour market in Turkey is particularly insecure for young people, women and poor-educated individuals; moreover, it poses considerable risks such that the labour market itself is directly precarious. The reconstruction of flexible labour markets under these negative conditions since the 2000s has established a situation in which employees to encounter increasingly precarious situations.

The flexibility of the labour markets in Turkey has been realised as a result of harmonisation policies that Turkey has pursued as part of the European Union membership process as well as due to European Commission directives (Taymaz and Ozler, 2004). The most important indicator of this process with regards to labour market policies is the labour law No. 4857 enacted in 2003. The most fundamental novelty introduced by this law into employment relations in Turkey is the arrangements pertaining to new non-standard contract types appearing in the labour market. Among the most crucial of these arrangements are contract types such as "part-time employment contracts," "temporary employment relationships" and "working on call," all of which can lead to the reconstruction of the labour market. However, this law provides some regulations that facilitate the applicability of various already-existing contract types, such as "subcontracting work." In fact, the new labour law is a result of attempts to formalise types non-standard insecure employment already available in the labour market in the past through legal legitimisation. This is summarised by Çelik as follows (2007: 126): The "new labour law is a text seeking answers not for the main subject of labour law of 'How to protect employees from the problems created by the market mechanism?' but for 'How the needs of the market will be met?"”

One of the most commonly-used non-standard employment contracts in Turkey is fixed-term employment based on the employer-subcontractor relationship. As pointed out by Mutevellioglu and Isik (2009: 184), "One of the flexible employment types (with the harshest results and wide use area) used in Turkey is employing workmen with subcontracting, which is a kind of flexibility implementation between the firms. To decrease the number of employees and reduce the workforce costs, mid-size enterprises conduct contract manufacturing in certain stages of production and transfer the gradually-increasing parts of many works previously carried out in the central enterprises to small subcontractor enterprises." This situation meant that most of the new jobs created in recent years were in the service sector; as such, the rate of employment in the service sector reached 48\% (CEC, 2008: 35). However, the jobs created in the service sector have a low quality and involve a workforce with low skills and productivity levels, which increasingly blurs the line between formal employment and informal employment in Turkey. This situation not only causes the labour market and employment relations in Turkey to multipartite and stratify, but it also has an influence in terms of the social problems it implies (Celik, 2007). 


\section{Methods}

This study aims to explore (i) how those who are employed under fixed-term employment contracts perceive job insecurity and job instability and experience precarious work situations and (ii) whether the experience of precariousness can be differentiated according to the variables of age, gender and educational level. A basic assumption of the study is that precarious experience is more severe for temporary employees in the service sector, and this severity depends on age, gender and educational level. To test this assumption, in-depth interviews were conducted with employees. Service workers interviewed were limited to those workers who have not had any regular or permanent work experience in the security and cleaning sectors in the last three years and who have work as a subcontractor on a fixed-term employment contract basis.

The service sector has expanded in the last decade in Bursa Province (one of the main industrial centres of Turkey), which is chosen as the area of study, as have the textile and automotive sectors, which are among the main sectors of the province as they serve as economic drivers for the city and the country. In particular, the increase in the number of the firms adopting outsourcing implementations since 2000 has caused the cleaning and security sectors to be among the sectors with new job creation. These sectors were chosen for the study, since employees in these sectors were working on a fixed-term employment contracts basis under mostly annual contracts. In addition, all firms were subcontracting, and the job changing rates of employees working in these firms were high. There are 67 cleaning companies and 41 security companies currently registered and operating in Bursa. In this study, we attempted to reach the largest firms of each sector operating in Bursa, and interviews were conducted in six firms, three of which were cleaning firms and the other three of which were security firms.

In-depth, semi-structured interviews were conducted, since the interview was based on both closed-ended and open-ended questions. The participants who were interviewed were initially asked various questions about how they experienced and perceived job insecurity. They were then asked to evaluate job instability. Finally, they were asked questions related to the influences of fixed-term employment on their careers and everyday lives. As the variation between participants was the determinant factor in the selection of interviewees, a maximum variation sampling method was used in this sample selection process. According to Patton (2002: 235), "this method of data collection will yield two kind of findings: high-quality, detailed descriptions of each case, which are useful for documenting uniqueness, and important shared patterns that cut across cases and derive their significance from having emerged out of heterogeneity." Using this method, indepth interviews were conducted with 21 participants, 10 of whom were cleaning workers and 11 of whom were security workers. To ensure a balanced gender distribution, particular caution was used to select the same number of women and men interviewees. Thirty years of age was accepted as the limit in the age distribution of the participating employees; participants below this age were coded as young people, and participants over this age were coded as adults. The duration of the interviews varied between thirty minutes and an hour, and all conversations recorded.

\section{Results}

In this study, results of the qualitative research are presented in three dimensions: experiences of job insecurity; perceived job instability and its effects on career-related issues; and precarious situations and everyday lives.

\section{Experiences of job insecurity}

Insecurity is a phenomenon shared by all participants. The most important indicators of insecurity include the high level of unemployment risk as a result of temporary employment and poor working conditions. Insecurity, which is emphasised by low-skil- 
led cleaning workers more than security workers, was articulated by participants as the direct effect of the temporary working on a fixed-term basis. One of the cleaning workers expresses his insecurity experience as follows:

\begin{abstract}
"We work on an annual contract basis. Of course, it is not clear what will happen when the contract terminates if you do not have close relations with company management. I have been working in this job for two years. For instance, my contract will terminate next month. Everyone is anxious about what will happen tomorrow. We fear for our future, job and life" (Male, aged 36, Secondary school).
\end{abstract}

Another cleaning worker in the same company explains what insecurity means to him as follows:

"In my opinion, there is such job insecurity at the moment. If I cannot make any future plans since I work in this job, if I have low income, and if I have to do a second job in addition to this job, it means that I do not have job security. Of course, I have health insurance. If we did not have this insurance, our condition would be much worse. However, if you work under annual contracts or six-month contracts, the possibility of being dismissed at the end of the year or at the end of the six-month period devastates you. There is already nothing relating to compensation. We can do nothing in the face of this situation. We are bound hand and foot, and therefore, we accept" (Male, aged 41, Secondary school).

The most crucial factor regarding this kind of insecurity experienced by cleaning workers is that these workers have low educational levels since cleaning works require low skills. After dismissed, they cannot find jobs rapidly, or they find unqualified jobs. Evaluating this fact together with the limitedness of the active and passive labour market policies in Turkey, the workers explain their felt insecurity with adjectives such as "fear" and "catastrophe." However, the in- security experienced by female participants differs from that of male participants. Insecurity is expressed by a female worker who had worked for two years in cleaning:

"I used to work in the houses as a casual labourer beforehand. I had a job to do just for one day, but the other day, I did not have any work to do. Of course, in this way, you work in a completely insecure job. You have neither health insurance nor employment insurance. Here, at least I am insured and feel more secure, and this job is more settled as compared to my previous job. However, it is open to discussion how sure this insurance is. In any event, it is the lesser evil" (Female, aged 44, Primary school).

As can be seen from the example above, most of the female cleaner interviewees have casual home cleaning work experience to provide additional income for the household. This induces them to evaluate their current jobs as relatively more secure. Furthermore, it can be argued that the gendered characteristics of cleaning means that women experience less insecurity in their jobs. The fact that all female cleaning workers over the age of 30 have casual work experiences leads them to perceive unemployment risk as less. However, there are also female cleaning workers who evaluate insecurity more severely. In this respect, the determinant criteria are age and educational level. Younger cleaning workers approach insecurity more critically. A high school graduate explains the situation as follows:

"We work since we have to work on a fixed-term basis. I am a high school graduate. I do not think I received quality training, but if you asked me if I want to work in a more secure and better permanent job with this education at this age, I surely would answer 'Yes.' Who wants to be a cleaning worker at this age?" (Female, aged 26).

The only worker with a four-year degree among the cleaning workers said: 
"The people around me found it strange and asked what major was appropriate for a university graduate to work as a cleaner. However, I had to work. I am accustomed to it... I graduated from the university two years ago. I looked for a job for a long time... I haven't got the social network. Since I could not find any job other than this, I started to work as a cleaner. I do not feel any negativity about the job; the only thing I consider is the money I have at the end of the month" (Male, aged 24, Bachelor's degree).

The ways in which young employees with relatively high levels of education accept jobs involuntarily increase the precarious experiences of them by enabling them to be more sensitive towards job insecurity in the cleaning sector. First, security sector workers are different from cleaning sector workers in that they approach this insecurity from a quite a different perspective. As a new working field, this sector provides employment for women as much as men. In addition, workers are certificated through a special training at least to the high school level, and job processes based on merit are listed as one of the reasons for this difference. Men working in different security companies articulate their opinions with regards to job insecurity as follows:

"In fact, insecurity in this job changes from company to company. Since we have project-based work, we have good working conditions as long as the company project is good. We select companies we will work for by taking this fact into account. I was very happy in many of the jobs I have worked to date, and I would be really happy to work for any of them again if they wanted so. In this sense, I am not able to say that I feel insecure. It does not matter to me to work under a fixed-term contract. Since I do my job happily, it is not very difficult for me to find a job in another company; I can say that I do not have much unemployment risk" (Male, aged 30, High school).

"The big demand in this sector brings great advantages. If you do your job well, you will not have any problems, like not being able to find a job. Of course, experience is very important as well. If you have some experience, instead of waiting for companies to choose you, you begin to choose companies after a while" (Male, aged 32, Associate degree).

"Although I started to work in this sector since I was urged by necessity, I am satisfied with my job today. Despite the economic crisis, there are security advertisements in the newspapers everyday. Although everyone who is unemployed is trying to receive a certificate now, I think this sector will expand more" (Male, aged 26, High school).

Comparing the evaluations of these three quotes from men in security with the cleaning workers, it appears that the perceived level of insecurity is lower among security workers. While being younger and having a level of higher education enable workers to be more sensitive towards their experience of precariousness in the cleaning sector, this is not true for the security sector. In other words, young people with a high level of education who are employed in security service think that their working conditions are safe, as they perceive their employment as an advantageous opportunity. The fact that the employability levels of those working in this sector are high is an ameliorating element with respect to insecurity.

\section{Perceived job instability and its effects on career-related issues}

Job instability, which is another feature of precarious employment in addition to insecurity, was articulated as a common problem by workers of both sectors. The disordered structure of their jobs influences the perceptions of workers with respect to their future careers. Cleaning workers answered the question "What does having a temporary job means to you?" as follows:

"To speak honestly, it does not mean much to me. In a sense, we got used to this situation. If you are a cleaning worker, you 
have to accept irregular jobs regularly. In a manner of speaking, our order is this disarrangement" (Male, aged 39, Secondary education).

"We go wherever the employer wants us to go. Sometimes, even I am confused when choosing which company I will work at during that week!" (Female, aged 44, Primary school).

An evaluation of another cleaning worker with regards to job insecurity is as follows:

"If you have to act under the principle that 'I do whatever there is to do,' you are forced to work in temporary jobs" (Male, aged 49, Primary school).

Considering these evaluations of cleaning workers, it is possible to say that one strategy of coping with job instability is to accept the situation by becoming indifferent to it. Both cleaning and security workers experience the feeling of despair in the face of the temporary nature of their jobs. Evidence of the same approach is revealed among security workers as well:

"All of the security men work completely under subcontracts. An employment method other than this cannot be considered for our sector. For that reason, individuals who prefer this job as an occupation choose it voluntarily and are aware of the situation. No one considers himself a permanent worker here. In any event, it is a subcontractor company. All the difficulties of the job are already definite beforehand, but it is a new sector, and it seems to hold many opportunities. Since there is a need for employees in the sector, you do not have any choice but to put up with these difficulties. You start to ignore whether the job is temporary or not" (Male, aged 25, Associate degree).

"Jobs are completely irregular. You are a security man in a buildings complex one year, but in the following year, you work in a shopping centre. You ensure the safety in both of them, but these are different jobs in practice. To speak honestly, I do not prefer building complexes. In that case, I have to leave that job. We have a nomadic working life!" (Male, aged 34, Associate degree).

The most direct influence of instability on employees is felt with respect to employee experiences of their career. The fact that the goal of having a long-term career particularly working in the same job disappears gradually is important evidence that employees are influenced by this instability. Evaluating the sectors in terms of career opportunities, it appears that job mobility of cleaning workers is only limited based on age, experience and personal abilities. A security man who has work experience of ten months answered the question "Could you evaluate having a temporary job in terms of your career targets?" as follows:

"I changed three jobs before I started to work in this company. All of these jobs were completely irrelevant to this job and the education I received in the university. I do not know how many times I will change job from now on. What upsets me is to be forced to work in a kind of irregular job after having received higher education for two years. In any case, I cannot see any future career for myself" (Female, aged 29, Associate degree).

Although another worker wants to advance in the same job in the future, he cannot envisage how this advancement will actually take place:

"I want to continue my career as a security
man. However, I do not know how things
will take place in the future; I cannot speak
definitely. I started to work in this job; I can
work in other jobs as well, but I think the
right thing to do is to stay in this job and
advance" (Male, 30, High School).

An emphasis on uncertainty regarding career paths and the future is shared by the workers of both sectors. Workers of both sectors are aware of the temporary nature of their jobs, and they have difficulty in making long-term plans about their jobs. Furthermore, when participants were asked about their opinions relating to the future of their working lives, they implied that they had not thought about 
this question previously. Uncertainty about the future was described by the workers as follows:

"The word 'career' is definitely an invalid
word for this sector" (Cleaning worker, Fe-
male, aged 32, Secondary education).
"I try not to think about the future. If you
work in a subcontractor firm, you cannot
see anything clearly. Your insurance is
paid late. Your wages are paid late. And
your working hours become flexible. What
could you expect from the future under
these conditions?" (Security guard, Male,
aged 26, High school).

\section{Precarious situations and everyday lives}

The expansion of precarious conditions in the service sector considerably influences the out-of-work daily lives of the workers of this sector. Considering the influences of precariousness on long-term plans, such as becoming a parent and having a child, as well as its influences on short-term daily life practices, such as leisure time activities, this study suggests that young workers in particular are more sensitive in this matter as compared to adults. Poor working conditions and unsecured and irregular jobs lead workers to lose their ability to control their lives. The adjustment of one's life according to these jobs not only damages the work-life balance, but it also blurs future expectations. The fact that the working hours of all of the participants taking part in this study ranged from 10 to 12 hours of shift work has a considerable influence on their daily lives. Flexibility in working hours is experienced by cleaning and security workers as follows:

"The arrangement of working hours in this way stops us from having a daily life. In fact, there is no point in complaining; we accept this situation voluntarily. However, the job itself is very hard, and when you work for many hours in this job, you want to go home immediately and you do not want to go out. I spend time at house during my off-days" (Cleaning Worker, Male, 39).

"I think it is too much for a person to work for ten hours a day. Our work does not finish here. We continue cleaning at home. I sometimes think about returning to being a casual home worker, but this job has insurance. I used to work from 9 a.m. until 5 p.m. In this way, you have time for yourself and for your family. Now it is very difficult" (Cleaning Worker, Female, 44).

"I experienced so many difficulties one year after I started to work that my life was upside down. Especially after you work from 8 p.m. to 8 a.m. during the night shift, and the shift occasionally reaches 15 hours when your other workmates are late for the morning shift. So you cannot spend regular time out of the job like other people do. I am single, and I am already thinking of quitting the job after getting married" (Security Guard, Male, 28).

Deep reflections on the influence of working hours on the lives of the participants suggest that they do not have a life outside of work, and they cannot take part in cultural activities in their leisure time. Moreover, they do not have sufficient time for their families. In addition, the role that precarious jobs play in the achievement of long-term goals is problematised, especially by young female workers interviewed in this study:

"I desire a regular life. I desire a life in which I could go to my job, deal with housework and spend time with my family. I do not think about getting married because of this job. I have to postpone my decisions. This is definitely not an appropriate job for a married woman!" (Security Guard, Female, 29).

"I have difficulty in making decisions pertaining to my life when I work on an annual-contract basis. You ask about five years later, but I cannot guess what will happen even one year later. I look at the future, but unfortunately, I cannot see anything. I live with my family. If I did not have them, it would be more difficult for me to earn a living. Sometimes, I think about buying a house or a car by getting credit from a bank, but it is not possible. It is very risky" (Security Guard, Female, 30). 


\section{Conclusion}

By taking the supposition of Fevre (2007) and Mills and his colleagues (2008) that "more various and multi-factoral data pertaining to the measurement of precariousness are needed into consideration", this study tried to put forth the experiences of the people employed in service sector in Turkey under fixed-term employment contracts, with regard to job insecurity and job instability. However, it is necessary to emphasize that the research had certain limitations: the fact that only cleaning and security sectors were chosen as service sector jobs, and that the number of firms which were chosen and the number of people interviewed was very small constituted the most important limitations of the research. It is necessary to mention that a generalization cannot be made, on the basis of the finding of this research, about the precarious situations of fixed-term employees working in the service sector in Turkey. In spite of the limitations of the research, some crucial clues were found with regard to service sector employees' ways of experiencing the precariousness.

Firstly, job insecurity was perceived by the participants as an appearance of the decrease in legal protection rights, deterioration in working conditions, increase of unemployment risk, threat of not finding a new job in the labour market after falling out of the job, and the loss of foresight relating to the future in working life. Secondly, job instability arose as a direct result of participants' working under temporary employment contracts since they lose their ability to build a career and postpone the short-term and long-term decisions about their lives. On the other hand, precariousness of the jobs of both sectors' workers and bad working conditions which they encountered did not prevent them from accepting the jobs though involuntarily. In other words, the fact that they accepted the jobs obligatorily, and the method of coping with this obligation by them was to be indifferent to the type of contract defined the precarious characteristics of their jobs.
As pointed out by Bujold and Fournier (2008), that precarious experience does not have a homogenous characteristics and the perception of precariousness presents variety in terms of different groups constituted one of the main suppositions of this research, as well. Heterogeneous structure of precariousness arose among the participants on the basis of some variables such as sector, gender, age and educational level. While the approach of cleaning workers to job insecurity was severer compared to the security guards, this severity increased especially for the higher-educated young people working in this sector. It is possible to clarify this circumstance with the fact that as educational levels of the young workers increase they encounter with more unemployment risks, in addition to the highness of young unemployment rate in Turkey. Moreover, the issue of mismatch between knowledge and skills young individuals gain at school and the necessities of the market increases the job insecurity levels of young workers who have high educational levels (Ercan, 2007). Irregularity of jobs is perceived as a negative situation by both young and adult employees in both sectors. It was seen that women were more sensitive than men in this matter. Considering the low rate of participation in workforce of women in Turkey, it is realized that having opportunity of employment increases the will for working in a regular job in the face of temporary work. It is possible to explain the more distant attitude of security guards compared to the cleaning workers in the face of job instability through the fact that security sector works are completely project-based. The situation in question led the individuals working in this sector to feel despair particularly about their career targets. The influence of precarious employment on everyday lives, one of the most important appearances of precarious employment among the employees, was the existence of uncertainty pertaining to future. Both male and female participants stressed that job instability played a direct role in the decisions such as starting a family, having a child and owning a property. 
In conclusion, considering the precarious structure of Turkish labour market during the process of economic and social integration with European Union, it is necessary to increase micro-level evaluations in addition to the macro-level ones so as to develop social policies relating to the employment (Selamoglu and Lordoglu, 2006: 235). In this sense, handling with flexibility policies -implemented extensively particularly in service sector in Turkey- together with Decent Work target will make it possible to develop policies for decreasing the multi-dimensional impacts of this negativity on labour market by enabling to problematize also the quality of the works created (Isigicok, 2005:141). This research should be seen as an effort to evaluate and understand the results of changing employment relations in Turkey in terms of temporary workers by trying to analyze the importance of precarious employment phenomenon within the context of service sector.

\section{REFERENCES}

Anker, R., I. Chernyshev, P. Egger, F. Mehran and J. A. Ritter (2003), "Measuring Decent Work with Statistical Indicators", International Labour Review, 142(2), pp.147-177.

Auer, P. (2006), "Protected Mobility for Employment and Decent Work: Labour Market Security in a Globalized World", Journal of Industrial Relations, 48(1), pp.21-40.

Bescond, D., A. Chataignier, and F. Mehran (2003), "Seven Indicators to Measure Decent Work: An international comparison", International Labour Review, 142(2), pp.179-211.

Boyer, R. (2006), "Employment and Decent Work in the Era of 'Flexicurity'" SA Working Paper No.32.

Bujold, C. and G. Fournier (2008), "Occupational Representations of Workers in Nonstandart and Precarious Work Situations", Journal of Career Assessment, 16(3), pp.339-359.

Commission of European Communities (CEC) (2008), Turkey 2008 Progress Report. (Retrieved May 10, 2009, from http:/ /ec.europa.eu/enlargement/pdf/ press_corner / key-documents / reports_nov_2008 / turkey_progress_report_en.pdf).

Çakır, Ö. (2007), "İşini Kaybetme Korkusu: İş Güvencesizliği", Çalışma ve Toplum, 12(1), pp.117-140.

Çelik, A. (2007), "Eğreti Emek-Parçalanan Sinıf", Birikim, No:217, pp.122-133.

Davoine, L., C. Erhel and M. Guergoat-Lariviere (2008a), A Taxonomy of European Labour Markets Using Quality Indicators, a project financed by DirectorateGeneral for Employment, Social Affairs and Equal Opportunities. 
Davoine, L., C. Erhel and M. Guergoat-Lariviere (2008b), "Monitoring Quality in Work: European Employment Strategy Indicators and Beyond", International Labour Review, 147(2-3), pp.163-198.

De Witte, H. and K. Näswall (2003), “'Objective' vs 'Subjective' Job Insecurity: Consequences of Temporary Work for Job Satisfaction and Organizational Commitment in Four European Countries", Economic and Industrial Democracy, 24(2), pp.149-188.

Elliott, L. and D. Atkinson (1998), The Age of Insecurity, London: Verso.

Ercan, H. (2007), Youth Employment in Turkey, Uluslararası Çalışma Örgütü: Ankara.

European Commission (2008), Employment in Europe 2008, Directorate-General for Employment, Social Affairs and Equal Opportunities, Luxembourg.

Fevre, R. (2007), “Employment Insecurity and Social Theory: the power of nightmares", Work, Employment \& Society, 21(3), pp.517-535.

Fields, G. S., (2003), “Decent Work and Development Policies", International Labour Review, 142(2), pp. 239-262.

Fournier, G., B. Bourassa, and K. Béji (2003), Work precariousness: A multifaceted reality. Québec, Canada: Les Presses de l’Université Laval.

Gallagher, D. and M. Sverke (2005), "Contingent Employment Contracts: are existing employment theories still relevant?", Economic and Industrial Democracy, 26(2), pp.181-203.

Gazier, B. (2002), “Introductory Remarks: Labour markets and transitions", in Peter Auer and Bernard Gazier (eds.), The Future of Work, Employment and Social Protection, International Institute for Labour Studies: Geneva, pp.27-32.
Ghai, D. (2003), "Decent work: concept and indicators", International Labour Review, 142 (2), pp.114-145.

Heery, E. and J. Salmon (2000), The Insecure Workforce, London: Routledge.

ILO (2008), Measuring decent work : tripartite meeting of experts on measurement of decent work, 8-10 Sept. 2008 (TMEMDW / 2008), International Labour Office: Geneva.

ILO (2009), Global Employment Trends: January 2009, International Labour Office: Geneva.

Işığıçok, Ö. (2005), 21. Yüzyılda İstihdam ve İnsana Yakışır İş, Ezgi Kitabevi: Bursa.

Işığıçok, Ö. (2009), “Küreselleşme Sürecinde İnsana Yakışır İş”, Sosyal Siyaset Konferaslar1 Dergisi, No:56, pp.307-331.

Kalleberg, A. L. (2000), “Non-Standart Employment Relations: Part-time, Temporary and Contract Work", Annual Review Sociology, Vol. 26, pp.341-365.

Mills, M., H.-P Blossgeld, S. Buchholz, D. Hofacker, F. Bernardi and H. Hofmeister (2008), "Converging Divergences?: An International Comparison of the Impact of Globalization on Industrial Relations and Employment Careers", International Sociology, 23(4), pp.561-595.

Mütevellioğlu, N. and S. Işık (2009), "Türkiye Emek Piyasasında Neoliberal Dönüşüm", Küreselleşme, Kriz ve Türkiye'de Neoliberal Dönüşüm içinde (der. Nergis Mütevellioğlu and Sinan Sönmez), pp.159-204.

Näswall K. and H. De Witte (2003), "Who Feels Insecure in Europe? Predicting Job Insecurity from Background Variables", Economic and Industrial Democracy, 24(2), pp.189-215. 
Patton, M. Q. (2002), Qualitative Research and Evaluation Methods, 3rd ed. Sage Publications: Thousand Oaks.

Saloniemi, A. and I.U. Zeytinoglu (2007), "Achieving Flexibility Through Insecurity: A comparison of work environments in fixed-term and permanent jobs in Finland and Canada", European Journal of Industrial Relations, 13(1), pp.109-128.

Schimd, G. (2002), “Employment Insurance for Managing Critical Transitions during the Life Cycle", in Peter Auer and Bernard Gazier (eds.), The Future of Work, Employment and Social Protection, International Institute for Labour Studies: Geneva,, pp.63-82.

Selamoğlu A. and K. Lordoğlu (2006), Kat1lım Sürecinde Avrupa Birliği ve Türkiye'de İşgücü ve İstihdamin Görünümü, AB'ye Sosyal Uyum Dizisi, Belediye-İş Yayınları: Ankara.

Sennett, R. (1998), The Corrosion of Character: The personal consequences of work in the new capitalism, W. W. Norton: New York.

Sverke, M. and J. Hellgren (2002), "The Nature of Job Insecurity: Understanding Employment Uncertainty and the Brink of a New Millenium", Applied Psychology: An International Review, 51(1), p.23-42.

Tansel A. and H. M. Taşçı (2004), Determinants of Unemployment Duration for Men and Women in Turkey, Institute for the Study of Labor (IZA) Discussion Paper No.1258.

Taymaz, E. and S. Özler (2004), Labour Market Policies and EU Accession: Problems and Prospects for Turkey, ERC Working Paper in Economics, Ankara.

Temiz, H. E. (2004), “Eğreti İstihdam: İşgücü Piyasasında Güvencesizliğin ve İstikrarsızlığın Yeni Yapılanması",Çalışma ve Toplum, 2(2), pp.55-80.
Toksoz, G. (2007), Women's Employment in Turkey, Uluslararası Çalışma Örgütü: Ankara.

Toksöz, G. (2009), “Neoliberal Piyasa ve Muhafazakâr Aile Kıskacında Türkiye'de Kadın Emeği", Küreselleşme, Kriz ve Türkiye'de Neoliberal Dönüşüm içinde (der. Nergis Mütevelliğioğlu ve Sinan Sönmez), pp.205-233.

Tucker, D. (2002), "'Precarious' Non-standard Employment-A Review of the Literature", Wellington, New Zealand: Labour Market Policy Group, Department of Labour. (Retrieved May 10, 2009, from http:/ / www.dol.govt.nz/publicationview.asp?ID).

Tunalı, İ. (2003), İstihdam Durum Raporu: Türkiye'de İşgücü Piyasası ve İstihdam Araştırması, Türkiye İş Kurumu: Ankara.

TÜİK (2009), Hanehalkı İşgücü Araştırması 2008 Yıllık Sonuçları, Ankara (Retrieved May 10, 2009, from http:/ / www.tuik.gov.tr/PreHaberBultenleri.do?id=4061).

Vosko, L. F. (2002), “'Decent Work': The Shifting Role of the ILO and the Struggle for Global Social Justice", Global Social Policy, 2(19), pp.19-46.

World Bank (2006), Turkey Labour Market Study, Report No. 33254-TR (Retrieved May 10, 2009, from http://siteresources.worldbank.org/INTTURKEY/Resources/361616-1144320150009/Labor_Stu dy.pdf).

Yıldırım, E. and S. Calış, (2008), “The Impact of EU Accession on Turkish Industrial Relations and Social Dialogue", Industrial Relations Journal, 39(3), pp.212-228.

Zeytinoglu, I.U. and J. Muteshi, (2000), 'Gender, Race and Class Dimensions of Nonstandard Work', Relations Industrielles/Industrial Relations, 55(1), pp.133167. 